\title{
EDUKASI PENCEGAHAN COVID 19 BAGI PENERIMA PROGRAM BANSOS DI DESA LONGOS KABUPATEN SUMENEP
}

\author{
Enza Resdiana1, Irma Irawati P. 2, Nur Inna Alfiyah3 \\ ${ }^{123}$ Fakultas Ilmu Sosial dan Ilmu Politik (Universitas Wiraraja) \\ ${ }^{1}$ E-mail address enza.resdiana@ gmail.com; 2 E-mail address Irma@ wiraraja.ac.id; \\ ${ }^{3}$ E-mail address nurinna@wiraraja.ac.id
}

\begin{abstract}
The rapid spread of Covid-19 has caused the government to adopt a "at home" policy by stopping various economic activities in the community. Health protocols that are carried out are maintaining distance, avoiding crowds, using masks, washing hands. As a form of implementation of Government policies, community empowerment is needed to minimize the number of Covid-19 cases, this empowerment is specifically aimed at rural communities with an interest in Social Assistance Recipients, given that the poor have low awareness of the importance of keeping free from exposure to Covid-19. . Therefore, empowerment will be carried out in the form of providing information and inviting social assistance recipients to live healthy lives and avoid exposure to Covid-19. The method of implementing activities in community service is by providing education which is carried out involving the recipient community of social assistance and interactive communication. The results of the implementation of community service activity programs in the form of providing covid-19 prevention education for social assistance recipients in Longos Village received enthusiasm and a positive response even though basically the community service team was only trying to provide additional insight for the community related to covid-19, how to avoid and prevent and change habits to be healthier by observing health protocols.
\end{abstract}

Keywords: education, community empowerment

\begin{abstract}
Abstrak
Cepatnya penyebaran Covid-19 menyebabkan pemerintah melakukan kebijakan "dirumah saja" dengan menghentikan berbagai kegiatan ekonomi masyarakat. Protokol kesehatan yang dilakukan yaitu menjaga jarak, menghindari keramaian, menggunakan masker, cuci tangan. Sebagai bentuk implementasi terhadap kebijakan Pemerintah perlu dilakukannya pemberdayaan masyarakat untuk meminimalkan jumlah kasus covid-19, pemberdayaan ini khususnya ditujukan untuk masyarakat desa yang berkepentingan dalam Penerimaa Bantuan Sosial, mengingat bahwa masyarakat miskin memiliki kesadaran yang rendah akan pentingnya menjaga agar terbebas dari paparan covid-19. Oleh sebab itu, pemberdayaan yang akan dilakukan dalam bentuk memberikan informasi dan mengajak masyarakat penerima bantuan sosial untuk hidup sehat dan
\end{abstract}


terhindar dari paparan covid-19. Metode pelaksanaan kegiatan dalam pengabdian masyarakat ini yaitu dengan pemberian edukasi yang dilakukan melibatkan masyarakat penerima bantuan sosial dan komunikasi interaktif. Hasil Pelaksanaan program kegiatan pengabdian kepada masyarakat berupa Pemberian edukasi pencegahan covid-19 bagi penerima bantuan sosial di Desa Longos mendapatkan antusias dan respon positif meski pada dasarnya tim pengabdian kepada masyarakat hanya berusaha untuk memberikan tambahan wawasan bagi masyarakat terkait dengan covid-19, cara menghindari dan mencegah serta merubah kebiasaan menjadi lebih sehat dengan memperhatikan protokol kesehatan.

Kata kunci: Edukasi, Pemberdayaan Masyarakat

\section{PENDAHULUAN}

Novel corona virus (CoV) adalah galur baru dari corona virus. Penyakit ini, yang disebabkan oleh novel corona virus yang pertama kali diidentifikasi di Wuhan, Tiongkok, diberi nama corona virus disease 2019 (COVID-19) Sebelumnya, penyakit ini disebut dengan '2019 novel corona virus'atau '2019nCoV.' COVID-19 adalah virus baru yang berasal dari satu keluarga yang sama dengan Severe Acute Respiratory Syndrome (SARS) dan beberapa jenis flu biasa. Covid-19 telah menjadi masalah di seluruh Dunia dimana pada saat ini dunia mencoba memerangi virus ini dengan melakukan berbagai kebijakan yang dilakukan. Virus covid-19 yang cepat dalam penyebarannya sehingga dibutuhkan berbagai upaya untuk mecegah virus ini menyebar.

Gejala yang dirasakan oleh penderita positif covid-19 ini mirip dengan flu (influenza) atau pilek biasa, yaitu demam flu sesak nafas yang jauh lebih umum daripada COVID-19. Untuk itulah diperlukan pengujian lebih lanjut untuk mengetahui apakah seseorang menderita infeksi novel coronavirus. Berikut perbedaan antara flu dan covid19 secara umum sebagai berikut:

\begin{tabular}{|c|c|c|c|}
\hline & PILEK & FLU & $\begin{array}{c}\text { CORONA } \\
\text { VIRUS }\end{array}$ \\
\hline $\begin{array}{c}\text { Waktu } \\
\text { inkubasi } \\
\text { dan gejala }\end{array}$ & 1-3 Hari & 1-4 Hari & 2-14 Hari \\
\hline $\begin{array}{c}\text { Gejala } \\
\text { timbul }\end{array}$ & Bertahap & Mendadak & Bertahap \\
\hline $\begin{array}{l}\text { Berapa } \\
\text { lama } \\
\text { gejala } \\
\text { berlangsu } \\
\quad \text { ng? } \\
\end{array}$ & $\begin{array}{l}7-12 \\
\text { Hari }\end{array}$ & 3-7 Hari & $\begin{array}{c}\text { Kasus ringan: } \\
2 \text { minggu } \\
\text { Kasus berat: } \\
3 \text { - } 6 \text { minggu }\end{array}$ \\
\hline
\end{tabular}

Sumber:

https://www.unicef.org/indonesia/id/co ronavirus

Update infografis percepatan Covid-19 di Indonesia per tanggal 11 juli 2020 oleh Badan Penanggulangan Bencana yang menyebutkan bahwa jumlah yang terpapar positif sebanyak 74.018 dengan 34.719 sembuh serta 3.535 meninggal, dengan banyaknya kasus yang terjadi banyak sekolah dan berbagai kegiatan dihentikan untuk mengurangi jumlah korban yang positif covid-19. Penyebaran yang bergitu cepat membuat pemerintah menghentikan berbagai kegiatan sekolah, pemerintahan dan kegiatan yang lain yang dilakukan secara berkelompok.

Cepatnya penyebaran Covid-19 menyebabkan pemerintah melakukan kebijakan "dirumah saja" dengan menghentikan berbagai kegiatan 
ekonomi masyarakat, berselang sekitar tiga bulan melaksanakan kebijakan tersebut dilakukan pelonggaran terhadap kegiatan masyarakat yang disebut dengan "new normal" dimana setiap kegiatan dapat dilakukan kembali akan tetapi sesuai dengan protokol yang ditetapkan oleh Pemerintah. Protokol kesehatan yang dilakukan yaitu menjaga jarak, menghindari keramaian, menggunakan masker, cuci tangan.

Sebagai bentuk implementasi terhadap kebijakan Pemerintah perlu dilakukannya pemberdayaan masyarakat untuk meminimalkan jumlah kasus covid-19, pemberdayaan ini khususnya ditujukan untuk masyarakat desa yang berkepentingan dalam Penerimaa Bantuan Sosial, mengingat bahwa masyarakat miskin memiliki kesadaran yang rendah akan pentingnya menjaga agar terbebas dari paparan covid-19. Oleh sebab itu, pemberdayaan yang akan dilakukan dalam bentuk memberikan informasi dan mengajak masyarakat penerima bantuan sosial untuk hidup sehat dan terhindar dari paparan covid19.

Berbicara tentang pemberdayaan,
berarti berbicara tentang proses penguatan masyarakat. Para ilmuwan sosial dalam memberikan pengertian pemberdayaan mempunyai rumusan yang berbeda-beda dalam berbagai konteks dan bidang kajian, artinya belum ada definisi yang tegas mengenai konsep tersebut. Namun demikian, bila dilihat secara lebih luas, pemberdayaan sering disamakan dengan perolehan daya, kemampuan dan akses terhadap sumber daya untuk memenuhi kebutuhannya.

Sulistiyani (2004) menjelaskan bahwa tujuan yang ingin dicapai dari pemberdayaan masyarakat adalah untuk membentuk individu dan masyarakat menjadi mandiri. Kemandirian tersebut meliputi kemandirian berpikir, bertindak dan mengendalikan apa yang mereka lakukan. Pemberdayaan masyarakat saat ini banyak dikaitkan dengan masyarakat desa. Hal ini dikarenakan rata-rata pola pikir masyarakat desa cenderung lebih terbelakang ketimbang masyarakat kota. Dengan demikian pemberdayaan masyarakat desa adalah proses membangun pola pikir dan kompetensi masyarakat desa agar bisa menyamai masyarakat kota atau bahkan bisa melebihi mereka. pemberdayaan masyarakat bertujuan untuk:

1) Melahirkan individu-individu yang mandiri dalam masyarakat.

2) Menciptakan masyarakat yang memiliki kesadaran tinggi akan potensi diri dan lingkungan di sekitarnya dengan baik.

3) Melatih dan memampukan masyarakat untuk melakukan perencanaan dan pertanggung jawaban atas tindakan mereka dalam memenuhi kebutuhan hidupnya.

4) Menambah kemapuan berpikir dan bernegosiasi atau mencari solusi terhadap permasalahanpermasalahan yang mungkin ditemui dalam lingkungannya.

5) Memperkecil angka kemiskinan dengan cara meningkatkan potensi dan kemampuan dasar yang dimiliki masyarakat

Pemberdayaan yang dilakukan dalam rangka menumbuhkan kesadaran masyarakat supaya lebih respon terhadap lingkungan dan berbagai kebijakan yang dilakukan. Untuk mengubah pola pikir masyarakat agar mampu untuk menghadapi masalah yang terjadi dilingkungan dibutuhkan upaya untuk memberikan edukasi kepada masyarakat agar lebih mampu untuk merespon situasi yang terjadi dilingkungan. Pemberdayaan yang akan dilakukan oleh tim pengabdian masyarakat merujuk pada para penerima bantuan sosial. Sasaran yang tepat untuk dijadikan sebagai tujuan untuk memberikan edukasi terkait dengan 
pandemi covid-19 yang dialami oleh seluruh dunia.

Untuk memberdayakan masyarakat agar mampu melaksanakan kebijakan yang dilakukan oleh Pemerintah terkait kebiasaan "new normal" maka perlu dilakukannya pemberian informasi yang terkait dengan protokol kesehatan sehingga covid-19 yang menjadi ancaman untuk masyarakat maka perlahan akan mengurangi jumlah yang terpapar covid19. Membentuk kebiasaan baru di masyarakat bukanlah hal yang mudah dibutuhkan pemberian informasi yang bertahap sehingga perubahan dapat dirasakan di lingkungan masyarakat itu sendiri. Seperti diketahui bahwa penerima bantuan sosial pada masa pandemi ini bertambah banyak bantuan sosial yang digalang dan diberikan untuk masyarakat miskin yang terkena dampak kebijkan pandemi. Bantuan tersebut diberikan kepada masyarakat diharapkan dapat membantu beban ekonomi, bantuan-bantuan tersebut seperti bantuan tunai langsung, bantuan dari kabupaten, bantuan dari pemerintah daerah dan pemerintah pusat serta bantuan sosial Program Keluarga Harapan (PKH), dengan memanfaatkan moment tersebut kegiatan pengabdian kepada masyarakat dilakukan untuk mengumpulkan penerima bantuan sosial dengan memberikan edukasi dan informasi terkait dengan covid-19.

Kegiatan pengabdian kepada masyarakat ini dilaksanakan dalam bentuk pemberian edukasi dan informasi kepada masyarakat mengenai pentingnya menjaga diri sendiri dan keluarga dari paparan covid-19 dengan menggunkan prosedur protokol kesehatan sesuai dengan anjuran pemerintah. Cara yang dilakukan kepada penerima bantuan sosial di Desa longos yaitu memberikan informasi terkait covid-19, cara menjaga keluarga dari paparan virus dan cara mengubah perilaku lebih sehat, cuci tangan yang baik dan sebagainya. Meskipun dalam kegiatan pengabdian tidak seluruh penerima bantuan sosial mendapatkan edukasi karena keterbatasan tempat maka edukasi yang diberikan dilakukan secara bertahap sesuai dengan protokol kesehatan.

Permasalahan mitra/kelompok sasaran Pengabdian Kepada Masyarakat adalah masyarakat belum mampu untuk menerapkan kebijakan "new normal" yang dianjurkan oleh Pemerintah, masyarakat desa merasa acuh terhadap covid-19 sehingga dibutuhkan informasi terkait dengan pencegahan covid-19 ini, kegiatan pengabdian ini juga membantu menularkan informasi positif dikalagan masyarakat untuk menerapkan protokol kesehatan yang dianjurkan selain itu juga dapat mengurangi tersebarnya covid-19 di Daerah Sumenep khususnya Desa Longos.

Solusi yang ditawarkan untuk permasalahan mitra adalah pemberian edukasi berupa sosialisasi, pendampingan berupa motivasi untuk menjaga kesehatan diri sendiri dan keluarga, memberikan praktek dalam mencuci tangan yang baik dan dapat memberikan perubahan perilaku masyarakat menjadi lebih sehat dan mengenali gejala-gejala yang ditimbulkan dari adanya covid-19.

\section{METODE DAN PELAKSANAAN}

Metode pelaksanaan kegiatan dalam pengabdian masyarakat dalam rangka memberikan edukasi dan pengetahuan kepada masyarakat mengenai pencegahan covid-19 dengan menggunakan beberapa metode :

a. metode edukasi yaitu memberikan Sosialisasi dengan melibatkan masyarakat penerima bantuan sosial mengenai beberapa bahasan tentang covid-19 dengan membahas sebagai berikut :

1) ancaman virus covid-19 
2) gejala yang ditimbulkan

3) cara mengantisipasi Coronavirus.

4) anak-anak beresiko terkena coronavirus,

5) Gerakan 3L yang harus dilakukan untuk menangkal coronavirus

6) 6 langkah cuci tangan yang benar agar terbebas dari virus

b. Komunikasi interaktif, dimana tim pengabdian kepada masyarakat membuka ruang komunikasi interaktif dengan mitra kerja untuk saling sharing mengenai virus covid-19 dan berbagai permasalahan yang ada dilingkungan masyarakat terkait penyebaran virus.

\section{HASIL DAN PEMBAHASAN}

Hasil kegiatan edukasi pencegahan covid-19 pada penerima Bantuan Sosial dengan menerapkan sesuai dengan protokol kesehatan mendapatkan respon positif dari masyarakat, beberapa masyarakat penerima bantuan sosial yang datang dalam pertemuan telah memakai masker meskipun untuk mengkondisikan supaya masyarakat mampu berjaga jarak dengan orang lain masih dilakukan pemberitahuan mengenai hal tersebut. Edukasi yang dilakukan oleh tim pengabdian kepada masyarakat terlaksana dengan maksimal dengan dibantu dengan kehadiran dan antusias masyarakat untuk mengetahui informasi mengenai pencegahan covid-19 yang menjadi masala bagi seluruh kalangan masyarakat.

Dalam pelaksanaan kegiatan pengabdian ditemukan masalah mengenai kurangnya keperdulian masyarakat untuk menjaga kebersihan, masih ada masyarakat yang jika bepergian keluar tanpa memperhatikan beberapa prosedur yang dianjurkan oleh Pemerintah seperti pemakaian masker untuk kegiatan di luar, masyarakat masih belum peduli terhadap kesehatan bersama, seperti diketahui bahwa jika memakai masker tidak hanya membantu diri sendiri untuk mencegah covid-19 akan tetapi dengan memakai masker juga dapat membantu orang lain terhindar dari penyakit covid-19 ini. Untuk itu dibutuhkan kesadaran yang penuh bahwa di pandemi covid-19 ini telah dilakukan kebijakan "new normal" dimana setiap masyarakat harus mampu secara mandiri menjaga keluarga dan lingkungan dari penyebaran covid-19.

Meskipun untuk saat ini berbagai kegiatan telah dilonggarkan dan diperbolehkan oleh Pemerintah, tidak serta merta masyarakat dapat kembali seperti dulu, ada perubahan perilaku yang diharapkan oleh Pemerintah terkait dengan adanya kebijakan baru, oleh sebab itu untuk membuka pemikiran masyarakat dibutuhkan informasi secara langsung kepada masyarakat terkiat dengan covid-19. Seperti yang dilakukan oleh tim pengabdian kepada masyarakat dapat memberikan dampak positif bagi Pemerintah dengan tersebarnya informasi pencegahan covid-19 dengan dapat merubah perilaku masyarakat yang lebih sehat. Ada beberapa kendala yang dihadapi oleh tim pengabdian kepada masyarakat salah satunya ada penyesuaian waktu pemberian edukasi yang kadangkala bentrok dengan kegiatan ibu rumah tangga, kendala yang lain terkait dengan latar belakang pendidikan ibu rumah tangga yang rendah sehingga untuk memberikan penjelasan secara teoritis terkait dengan penyebaran covid-19 kepada ibu-ibu diperlukan berbagai upaya agar ibu-ibu dapat mengerti dan paham dengan yang dilakukan oleh tim. Adanya kendalakendala yang disebutkan tersebut perlu menjadi perhatian apabila dilain waktu 
dan kesempatan dilaksanakan pengabdian masyarakat kembali di masa yang akan datang.

Kegiatan pengabdian kepada masyarakat di Desa Longos mendapat respon dan dukungan serta sambutan yang sangat baik dari berbagai instansi setempat seperti Aparatur Desa yang menghubungkan tim dengan masyarakat penerima bantuan, ibu-ibu rumah tangga yang ikut berpartisipasi dalam pemberian edukasi terkait dengan pencegahan covid-19 merupakan dukungan terbesar. Dengan adanya edukasi pencegahan covid-19 ini masyarakat secara mandiri dapat melindungi diri sendiri dan keluarga dari terpaparnya covid-19, meskipun pada dasarnya masyarakat masih menyepelekan covid-19 ini dengan masih bekerja tanpa masker dan masih berinteraksi dengan orang lain tanpa menjaga jarak. Oleh karena itu, edukasi dilakukan untuk memberikan pengetahuan kepada masyarakat sehingga pikiran masyarakat menjadi terbuka dan menjadi lebih peduli terhadap kesehatan keluarga. Edukasi ini juga menjelaskan mengenai ancaman anak-anak terhadap paparan covid-19 jauh lebih besar sehingga dibutuhkan penjagaan khusus untuk menjaga anak agar terhindar dari covid-19. Berikut adalah gambar pemberian edukasi kepada penerima bantuan sosial di Desa longos yang mendapatkan respon positif.

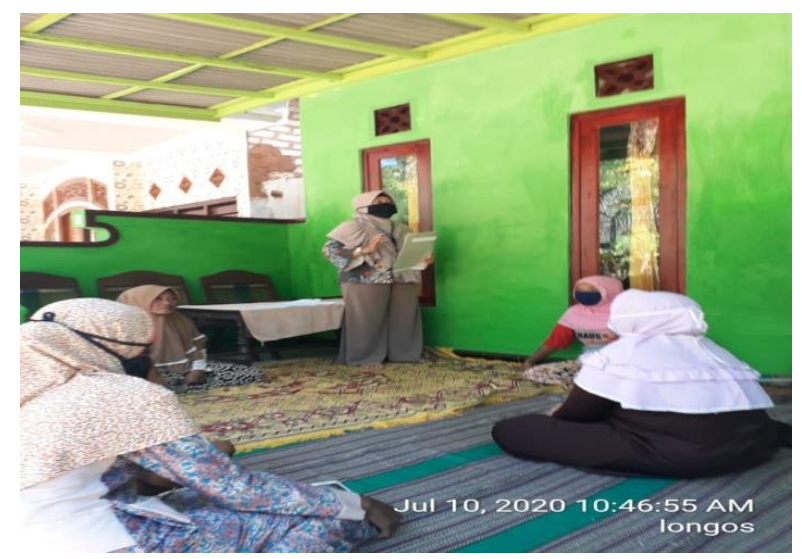

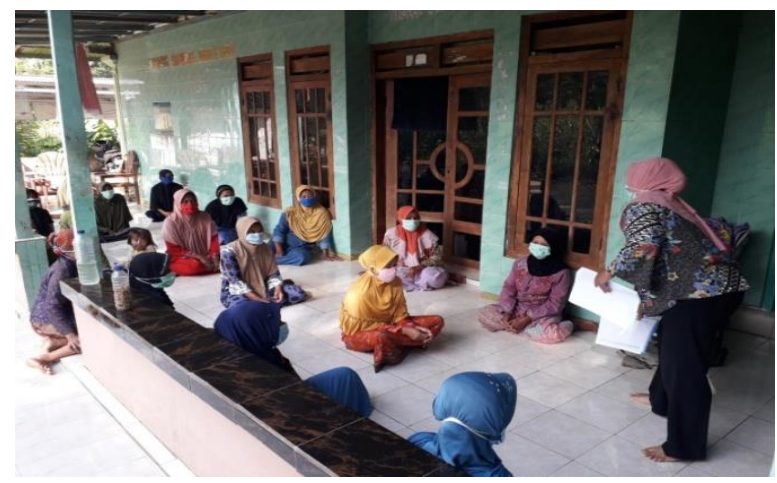

Gambar 1 .

Kegiatan edukasi pencegahan covid 19 dengan menggunakan protokol kesehatan di Desa Longos Gapura

Dengan adanya pelatihan ini akan menambah kesadaran masyarakat untuk menjaga kesehatan keluarga agar terbebas dari paparan ovid-19 dan jika ada gejala-gejala yang sesuai dengan gejala covid-19 dapat ditangani secara mandiri dan akan mendapatkan penanganan yang baik dengan begitu penyebaran covid-19 akan semakin sedikit. Edukasi yang diberikan ini juga memberitahukan kepada ibu-ibu rumah tangga untuk melindungi anak-anak mereka dengan menggunakan protokol kesehatan seperti: rutin cuci tangan pakai sabun atau cairan pembersih tangan berbasis alkohol minimal 60\%, tutupi mulut dan hidung dengan bagian dalam siku atau tisu ketika batuk atau bersin, lalu segera buang tisu yang telah digunakan, dan hindari kontak langsung dengan orang yang sedang batuk atau bersin. Selain itu, orang tua juga disarankan untuk selalu membawa cairan pembersih tangan, tisu sekali pakai, dan tisu disinfektan pada saat keluar rumah karena hal itu akan berguna untuk membersihkan tempat duduk, sandaran tangan, layar sentuh, dan lain-lain.

Selain itu tim pengabdian kepada masyarakat juga memberikan informasi terkait dengan Gerakan 3L yang harus di ingat dan dilakukan untuk menangkal coronavirus yaitu dengan gerakan 
Lindungi diri sendiri, Lindungi keluarga dan Lindungi orang sekitar. Dengan adanya edukasi ini diharapkan masyarakat desa Longos mampu secara mandiri menerapkan protokol kesehatan yang baru dan jumlah yang terinfeksi covid-19 akan semakin menurun dan sedikit.

\section{PENUTUP}

\section{Simpulan}

Pelaksanaan program kegiatan pengabdian kepada masyarakat berupa Pemberian edukasi pencegahan covid-19 bagi penerima bantuan sosial di Desa Longos mendapatkan antusias dan respon positif meski pada dasarnya tim pengabdian kepada masyarakat hanya berusaha untuk memberikan tambahan wawasan bagi masyarakat terkait dengan covid-19, cara menghindari dan mencegah serta merubah kebiasaan menjadi lebih sehat dengan memperhatikan protokol kesehatan. selain itu penting juga untuk menjaga anak dan keluarga dari paparan covid-19 dengan menggunakan disinfekta. Rekomendasi yang dapat diberikan Rendahnya pengetahuan masyarakat desa mengenai pencegahan covid-19 dimana masyarakat desa masih menganggap hal tersebut sebagai hal yang sepele sehingga hal tersebut merupakan masalah utama dalam penerapan new normal untuk mencegah penyebaran covid-19.

\section{Saran}

Menghadapi new normal terutama untuk masyarakat desa Longos perlu diadakan pemantauan secara berkala agar masyarakat tetap melaksanakan protokol kesehatan, terutama di tempattempat keramaian agar masyarakat tidak mengentengkan bahaya dari Covid-19 ini.
Terimakasih kepada tim pengabdian mandiri yang telah melakukan pengabdian dengan baik dan lancar, serta kepada Fakultas Ilmu Sosial dan Ilmu Politik Universitas Wiraraja dalam memberikan fasilitas kelengkapan dokumen yang dibutuhkan selama pelaksanaan pengabdian ini berlangsung.

\section{DAFTAR PUSTAKA}

Arikunto, S. 2010. Prosedur Pengabdian

Masyarakat: Suatu Pendekatan

Suharto, Edi. 2005. Membangun

Masyarakat Memberdayakan

Masyarakat. Timur Bandung:

PT.Refika Aditama.

Harvard Medical School. Coronavirus:

Many questions, someanswers.

CDC. 2019. diakses di

https://www.cdc.gov/coronavirus/

2019-ncov/faq.html

WHO. 2020. Diakses di

https://www.who.int/news-

room/q-a-detail/q-a-coronaviruses

WHO. 2019. Diakses di

https://www.who.int/emergencies/

diseases/novelcoronavirus-

2019/advice-for-public/

UNICEF. 2020. Diaksses di

https://www.unicef.org/indonesia/ $\underline{\mathrm{id} / \text { coronavirus }}$ 